\title{
Content of Arsenic in Market-Ready Rainbow Trout (Oncorhynchus mykiss)
}

\author{
Z. SVOBODOVÁ ${ }^{1,2}$, O. ČELECHOVSKÁ ${ }^{2}$, J. MÁCHOVÁ $^{1}$, T. RANDÁK ${ }^{1}$ \\ University of South Bohemia, Research Institute of Fish Culture and Hydrobiology, Vodňany, Czech Republic, \\ ${ }^{2}$ University of Veterinary and Pharmaceutical Sciences, Brno, Czech Republic \\ Received January 24, 2002 \\ Accepted June 19, 2002 \\ Abstract \\ Svobodová, Z., O. Čelechovská, J. Máchová, T. Randák: Content of Arsenic in \\ Market-Ready Rainbow Trout (Oncorhynchus mykiss). Acta vet. Brno 2002, 71: 361-367. \\ The aim of this study was to assess the content of arsenic in market-ready rainbow trout \\ (Oncorhynchus mykiss) which have been grown intensively and fed feeding mixtures containing \\ fish meal and krill meal. Tissue samples analysed were of rainbow trout from 8 trout farms in the \\ Czech Republic and from a station for biological checking the water quality at water processing \\ plant in Prague Podolí. Samples of the feeds were analysed as well. Analysis comprised 74 muscle \\ samples and 4 feed samples in total. Brown trout from nature was used as comparative material. \\ Arsenic was determined by means of HG AAS method. The content of arsenic in muscle of rainbow \\ trout from the trout farms under study, as well as from the biological check station can be assessed \\ as strongly increased compared to values recorded in brown trout from nature $\left(0.12 \pm 0.07 \mathrm{mg} \cdot \mathrm{kg}^{-1}\right)$. \\ In case of two trout farms and of the biological check station, the arsenic content recorded exceeded \\ the hygienic limit of $1 \mathrm{mg} \cdot \mathrm{kg}^{-1}$ valid for freshwater fish. Regression analysis of data proved \\ a significant correlation $(\mathrm{r}=0.57-0.94)$ between arsenic content in muscle and fish weight. \\ Arsenic content in BIOMAR and ALLER feeds ranged in $2.5-3.1 \mathrm{mg} \cdot \mathrm{kg}^{-1}$. Results showed that \\ the increased concentration of arsenic in muscle of marke-ready rainbow trout was due to presence \\ of arsenic in feed. Based upon these facts, we recommend to pay attention to the problem in the \\ near future and mainly to speciate arsenic compounds. \\ Muscle, fish weight, commercialfeed, AAS
}

Arsenic enters the aquatic environment naturally or due to anthropogenic pollution. Volcanic blow-outs, forest fires and weather effects as e.g. erosion are natural sources of arsenic. It comes to water by pyrite oxidation as arsenate. Subsequently, it can bind to hydrated arsenite oxide which deposits as a part of sediments (Jarěs et al. 2000). Among the most serious anthropogenic sources of arsenic, there are emissions and effluents from metal mining and processing industry, production of dyes from tanneries, thermal power plants, application of some insecticides and herbicides, from timbering, etc. According to the fact that arsenic comes with phosphorus, it is present also in effluents from laundrying (Tamaki et Frankenberger 1992; Pitter 1999).

Arsenic has a high ability to cumulate in bottom sediments (Pitter 1999). For this reason, increased attention is paid to the problems of arsenic content in aquatic organisms, above all in marine invertebrates and in fish (Khokiattiwong et al. 2001; Kirby et al. 2001; De Gieter et al. 2001).

In countries with high seafood consumption, aquatic organisms make an important portion of the dietary dose of arsenic in human. Marine fish and mainly marine crustaceans and molluscs strongly accumulate arsenic compounds. These toxic compounds of arsenic are transformed in their organisms to arsenobetain, arsenocholin and to other organic compounds which are substances nearly non-toxic for human organism (Velíšek 1999). Although inorganically bound arsenic is not the main component of total arsenic content in marine organisms, it represents a potential toxicity risk. The rate of inorganically bound

Address for correspondence:

Prof. MVDr. Zdeňka Svobodoyá, DrSc.

University of South Bohemia České Budějovice

389025 Vodñany, Czech Republic
Phone: +420342382402

Fax: + 420342382396

http://www.vfu.cz/acta-vet/actavet.htm 
arsenic from the total arsenic content makes up to $44 \%$ in samples of marine fish, crustaceans and molluscs. The ratio of individual components is changing with species of fish and with environment, e.g. the anorganic component is lower in fish of fresh running waters (up to 27\%) (EPA 2000).

No any considerable attention has yet been paid to the problem of arsenic in freshwater fishes in the Czech Republic. Published data comprised values of total arsenic content in indicator fishes of Elbe River and its pools (Čelechovská et al. 2001), in fishes of North Moravian reservoirs Kružberk, Šance and Morávka (̌̌ehulka 2001) and in market-ready common carp from Regent pond (Žlábek et al. 2002). In most of the fish analysed, the content of arsenic in muscle was below $0.1 \mathrm{mg} \cdot \mathrm{kg}^{-1}$, only 7 specimens of perch caught from Elbe River at Hradištko locality showed a value of $\mathrm{x} \pm \mathrm{SD}: 0.146 \pm 0.124 \mathrm{mg} \cdot \mathrm{kg}^{-1} \mathrm{As}$ in fresh tissue. In all cases, the arsenic content fulfilled the limits of the decree of Ministry of Health of the Czech Republic No. 298/1997, approving the highest acceptable amount of arsenic in freshwater fishes as $1 \mathrm{mg} \cdot \mathrm{kg}^{-1}$ in fresh tissue (further referred to as hygienic limit).

Checking the arsenic content in muscle of market-ready rainbow trout from a trout farm in the Czech Republic, the values found were close to $1 \mathrm{mg} \cdot \mathrm{kg}^{-1}$ and higher. This became an impulse for extended checking the arsenic content in this fish species. Parallel to the analysis of fish, analysis of the feeds administered to them was performed as well. These were foreign commercial feeds containing fish meal and krill (marine crustacean Euphausia superba) meal, both of marine products.

Results of this investigation are presented in this paper.

\section{Materials and Methods}

The first sampling of muscle of market-ready rainbow trout (Oncorhynchus mykiss) for the determination of arsenic was performed in January 2000 on trout farm No. 1 in West Bohemia. Altogether 18 specimens were sampled. Further sampling was performed on 7 trout farms (Nos. 2 - 8) in the Czech Republic during June - August 2001. It comprised 2 trout farms in North Moravia, 2 trout farms in South Bohemia, 1 trout farm in West Bohemia, 1 trout farm in Central Bohemia and 1 trout farm in Czech-and-Moravian Highlands. In all cases, fish have been fed throughout the entire growing period by commercial feeds from renowned foreign companies (ALLER feed at farm No. 3 and BIOMAR feed at all other farms). Seven fish were sampled at every farm, age of the fish was 2 years. They were weighed, dorsal muscle sample was taken, put into a microtene bag and placed into a thermostable styrofoam box. After arrival to the laboratory, samples were placed into a freezer at $-18{ }^{\circ} \mathrm{C}$.

Seven specimens of rainbow trout were sampled at a station for biological checking the water quality at water processing plant Prague Podolí in October 23, 2000. Rainbow trout was used here for checking the quality of raw water brought to the processing plant. Trouts were stocked as quarter-yearlings, reared for 1 year and thoroughly examined, comprising weighing and determination of arsenic content (Svobodová et al. 1995; Randák et Pokorný 2001). Fish sampled for the examination were of the same age (1.25 year). They have been fed BIOMAR feed for the entire growing period. Besides muscle samples, liver and kidney were sampled in these fish as well.

Feeds obtained from the centre of the feed distribution network for trout farms during the second half of 2001 were analysed as well. It concerned Danish feed BIOMAR (for marketable fish) and BIOMAR (for fry - $2 \mathrm{~mm}$ ), as well as German feed ALLER (for marketable fish). A sample of BIOMAR feed (for marketable fish) was also taken for analysis from the station for biological checking the water quality in Prague Podolí on November 23, 2000.

Individual muscle samples were processed in three parallel weigh-outs of every fish. Liver samples taken from fish at the station for biological checking the water quality in Prague Podolí, were analysed in $2-3$ parallels according to liver size; kidney samples from these fish were processed as 1 pooled sample of all 7 fish. Samples of feeds were processed in 5 parallels.

A weigh-out of a sample was firstly mineralised with nitric acid and hydrogen peroxide in laboratory autoclave with microwave heating (Uniclever, Plasmatronica) and then after adding magnesium nitrate it was burnt in muffle furnace at $450{ }^{\circ} \mathrm{C}$. Ash was dissolved in hydrochloric acid and $\mathrm{As}^{\mathrm{V}}$ was reduced to As ${ }^{\mathrm{III}}$. Feed samples were processed similarly. Arsenic was determined by means of hydride technique at MHS - 20 device attached to atomic absorption spectrophotometer Z - 5000 (all from Perkin Elmer). Detection limit was $1 \mu \mathrm{g} \cdot \mathrm{kg}^{-1}$, standard deviation of parallels was less than 5\%. The method was validated by means of reference standard material CRM No 278 (mussel tissue of Mytilus edulis - BCR) and MA-B-3/TM (fish homogenate-IAEA).

The content of arsenic in muscle samples (fresh tissue) of marketable rainbow trout from intensive culture was compared to that recordered in brown trout $(n=5)$ gained from natural environment of Karolinka dam reservoir. These fish were grown on natural feed sources. Their mean age was 2.25 year.

The values of arsenic content in muscle and in other tissues of fish are given in $\mathrm{mg} \cdot \mathrm{kg}^{-1}$ of fresh tissue. The values 
of arsenic content in feeds are given in $\mathrm{mg} \cdot \mathrm{kg}^{-1}$ of dry matter. Results were tested by statistical package Unistat ${ }^{\circledR}$, version 5.1 .

\section{Results}

The values of arsenic content in muscle (fresh tissue) of market-ready rainbow trout from 8 trout farms in the Czech Republic are stated in Table 1. The content of arsenic in muscle of trout from all farms under study can be assessed as strongly increased, if compared to the values registered in muscle of brown trout from natural environment. The highest values were registered at trout farms No. 1 and 2, even exceeding the hygienic limit valid for freshwater fish $\left(1 \mathrm{mg} \cdot \mathrm{kg}^{-1}\right)$. The limit was exceeded in 9 specimens from trout farm No. $1(50 \%)\left(1.33 \pm 0.20 \mathrm{mg} \cdot \mathrm{kg}^{-1}\right)$ and in 1 specimen from trout farm No. 2 $(14.3 \%)\left(1.12 \mathrm{mg} \cdot \mathrm{kg}^{-1}\right)$.

Table 1

Arsenic content in muscle of market-ready rainbow trout from trout farms in the Czech Republic

\begin{tabular}{|c|c|c|c|c|c|}
\hline \multirow{2}{*}{ Trout farm } & \multirow{2}{*}{$\begin{array}{c}\text { Date of } \\
\text { sampling }\end{array}$} & $\begin{array}{c}\text { No. of } \\
\text { specimens (a) }\end{array}$ & $\begin{array}{c}\text { Fish } \\
\text { weight g }\end{array}$ & \multicolumn{2}{|c|}{ Arsenic content in fish muscle $\mathrm{mg} \cdot \mathrm{kg}^{-1}$} \\
\cline { 5 - 6 } & 26.1 .99 & 18 & $347 \pm 48.4$ & $1.133 \pm 0.239$ & $0.904-1.414$ \\
\hline 1 & 22.6 .01 & 7 & $414 \pm 82.6$ & $0.929 \pm 0.118$ & $0.732-1.123$ \\
\hline 2 & 22.6 .01 & 7 & $294 \pm 50.3$ & $0.732 \pm 0.159$ & $0.505-0.973$ \\
\hline 3 & 26.7 .01 & 7 & $269 \pm 41.1$ & $0.541 \pm 0.117$ & $0.364-0.690$ \\
\hline 4 & 26.7 .01 & 7 & $270 \pm 36.7$ & $0.601 \pm 0.116$ & $0.470-0.806$ \\
\hline 5 & 30.7 .01 & 7 & $257 \pm 95.2$ & $0.596 \pm 0.154$ & $0.415-0.795$ \\
\hline 6 & 30.7 .01 & 7 & $286 \pm 21.7$ & $0.710 \pm 0.123$ & $0.512-0.860$ \\
\hline 7 & 7.8 .01 & 7 & $238 \pm 37.4$ & $0.498 \pm 0.056$ & $0.407-0.577$ \\
\hline 8 & & & & & \\
\hline
\end{tabular}

The relationship of arsenic content in muscle to fish weight was proven as significant $(r=0.57)$ (Fig. 1) for the respective trout farms No. 2 - $8(n=49)$. Even closer relationship of arsenic content in muscle to fish weight was proven for the file of mean values from all trout farms studied, with the correlation coefficient recorded $\mathrm{r}=$ 0.94 (Fig. 2).

The content of arsenic in muscle, liver and kidney of rainbow trout sampled at the station for biological checking the water quality in Prague

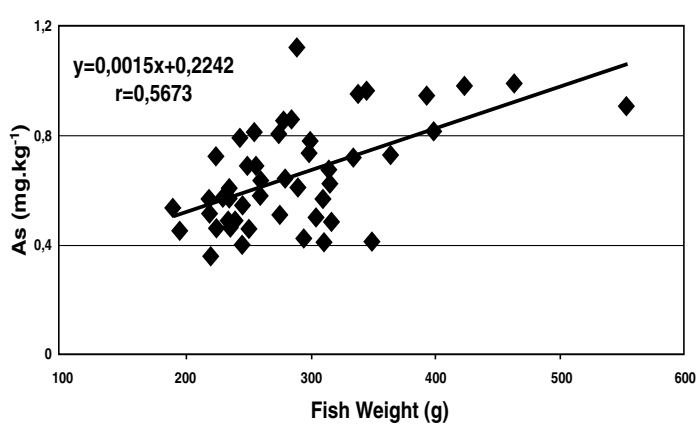

Podolí is given in Fig. 3. Weight of these fish ranged in $158-210 \mathrm{~g}$. High content of arsenic in muscle of fish was detected at this locality as well; the hygienic limit $\left(1 \mathrm{mg} \cdot \mathrm{kg}^{-1}\right)$ was exceeded in 5 specimens out of 7 . The content of arsenic in liver of these fish was about 5 fold lower and in kidney 3.5 fold lower than that in muscle.

The content of arsenic in samples of pelleted feed BIOMAR (fry $-2 \mathrm{~mm}$ ) and BIOMAR(market-ready fish) sampled in 2001 was $3.08 \pm 0.51 \mathrm{mg} \cdot \mathrm{kg}^{-1}$ and $2.89 \pm 0.35$ $\mathrm{mg} \cdot \mathrm{kg}^{-1}$, respectively. In the sample of ALLER feeds, the content of arsenic was $2.49 \pm 0.19 \mathrm{mg} \cdot \mathrm{kg}^{-1}$ (result of 5 parallel determinations). The content of arsenic in feed 


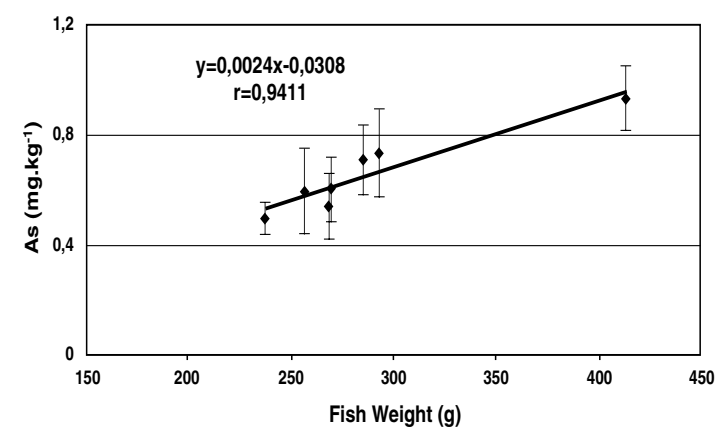

Fig. 2. Relationship of mean concentrations of arsenic in muscle of rainbow trout and their weight (mean weights recorded on individual trout farms)

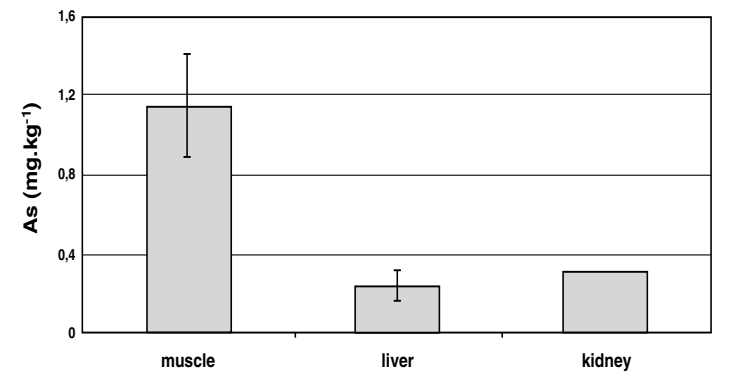

Fig. 3. The content of arsenic in tissues of rainbow trout from the station of biological checking the water quality in the water processing plant in Prague Podolí (November 23, 2000) sample BIOMAR (marketable fish) that has been sampled at the station for biological checking the water quality in Prague Podolí in 2000 was 1.78 $\pm 0.20 \mathrm{mg} \cdot \mathrm{kg}^{-1}$.

In the brown trout used for comparison (5 specimens, mean age 2.25 year) originating from natural environment of Karolinka dam reservoir, the content of arsenic in muscle was $0.12 \pm 0.07 \mathrm{mg} \cdot \mathrm{kg}^{-1}$.

\section{Discussion}

The content of arsenic detected in muscle of market-ready rainbow trout from intensive culture was up to 10fold higher than that in brown trout of nearly the same age but from natural environment. Although brown trout is another species, it was used for comparison. It is very difficult to find a locality with natural occurrence of rainbow trout under our conditions. The majority of rainbow trout caught in running waters are fish that have been stocked from intensive culture and therefore with already increased content of arsenic in muscle. Rehulka (2001) reported for 3-year-old rainbow trout weighing $194 \mathrm{~g}$ and $400 \mathrm{~g}$ from natural environment of Morávka dam reservoir values of arsenic 0.050 to $0.090 \mathrm{mg} \cdot \mathrm{kg}^{-1}$ muscle. Most trout farms studied are located in upper parts of rivers with no sources of anthropogenic contamination with arsenic. Due to this fact it was hypothesized that the main source of arsenic in musle of marketable rainbow trout was arsenic contained in the administered feed. High correlations found for the content of arsenic in muscle and the weight of marketable rainbow trout support this hypothesis.

Feeds of renowned foreign producers BIOMAR (Denmark) and ALLER (Germany) were used for feeding the examined rainbow trout at trout farms and at the station for biological checking the water quality in Prague Podolí. Varying content of arsenic was found in two different lots of BIOMAR (market-ready fish) feed $\left(1.8\right.$ and $\left.3.1 \mathrm{mg} \cdot \mathrm{kg}^{-1}\right)$. The content of arsenic in feeds seems to be variable and depending on the content of arsenic in sources of marine products. According to the Decree of the Ministry of Agriculture No.194/1996 Annex 3, the highest admissible content of arsenic in complete feed for fish is $4 \mathrm{mg} \cdot \mathrm{kg}^{-1}$. All feeds under study fulfilled this limit.

Based on the detected values of arsenic content found in the feed, in muscle of marketable rainbow trout from intensive culture and on the mean feeding coefficient $(0.95-1.15)$ (Pokorný et al. 1998), we can estimate the ratio of cumulation and elimination of arsenic in these fish. It can be seen from this estimation that about $20-30 \%$ of arsenic ingested with feed is cumulated while the rest is metabolised and eliminated. We suggest it important to point out that this state was estimated for trout analysed in June-August, i.e. during the growing season. 
It is necessary to evaluate the increased content of arsenic in muscle of market-ready rainbow trout either from the point of view of its effect on fish health, or from the point of view of health risk for consumers. Cockell et al. (1991) showed that a feed containing $13 \mathrm{mg} \cdot \mathrm{kg}^{-1}$ arsenic which has been administered for 24 weeks did not affect health negatively, nor it caused lesions in gall bladder of rainbow trout. (Chronical inflammatory alterations in subepitelial tissue of gall bladder of rainbow trout indicate sensitively a chronical dietary exposure to arsenic). Unfortunately, this paper did not mention the content of arsenic in tissues of the treated trout.

Based upon these data it can be anticipated that feeds containing ca. $3 \mathrm{mg} \cdot \mathrm{kg}^{-1}$ arsenic would not induce changes in health status of market-ready rainbow trout. The health risk assessment for humans due to consumption of these fish is performed either by comparing the values of arsenic content in muscle to the valid hygienic limit, or by speciation of arsenic compounds in muscle of these fish. Concerning the marketable rainbow trout from 8 trout hatcheries in the Czech Republic, the hygienic limit was exceeded in $15 \%$ of analysed fish but only in $2 \%$ of samples that have been taken during summer period. Speciation of arsenic compounds was not performed in this study due to methodical reasons. Nevertheless, Shiomi et al. (1995) who analysed market-ready rainbow trout from intensive culture, found arsenobetain to be the main compound in muscle of the fish. Furthermore, they reported commercial feeds to be the main source of arsenobetain.

A whole series of papers is currently focused to the problem of speciation of arsenic compounds in biological material, above all in organisms of the aquatic environment (Le et al. 2001; Pergantis 2001; Kaise et al. 2001). Speciation becomes an essential part of biological monitoring. Nevertheless, methods used for this purpose are expensive and time consuming. Further problems are with reference standards of individual arsenic compounds in the biological matrix, as they are yet of low availability (Čelechovská 2001).

Content of arsenic in muscle of rainbow trout sampled from the biological station for checking the quality of water brought to the water processing plant in Prague Podolí was also found increased and in $71 \%$ of specimens exceeding the hygienic limit $1 \mathrm{mg} \cdot \mathrm{kg}^{-1}$. This percentage was much higher compared to that found in marketable rainbow trout from the trout farms, despite of lower age and lower weight of the trout from the biological station, as well as lower arsenic content in feed administered to them. Different water temperature and thus differing metabolic rate at the time of sampling the fish for analyses seemed to be one of possible explanations. At the trout farms, fish were sampled for analyses starting in June 22, till August 7, 2001. Sampling at the biological station was done in November 23, 2000. Similarly, muscle samples of rainbow trout sampled from trout farm No.1 in January 1999 also showed higher values. This could refer to the literature (Chan and Huff 1997), reporting that periods of higher metabolic transformation and elimination can alternate in the organism with a tendency of arsenic accumulation in tissues. Apart from that, there could be some other circumstances, e.g. detoxication metabolism decreased during a diet with low content of methionin, cholin or proteins, due to which there is a decreased elimination of methylated compounds of arsenic from the organism and in concert of that an increased cumulation of arsenic in tissues (Chan and Huff 1997).

\section{Obsah arsenu u tržních pstruhů duhových (Oncorhynchus mykiss)}

Cílem práce bylo zhodnotit obsah arsenu u tržních pstruhů duhových (Oncorhynchus mykiss) krmených krmnými směsmi s obsahem rybí a krylové moučky v podmínkách intenzivního chovu. Analyzovány byly vzorky tkání pstruhů duhových z 8 pstruhařství ČR a jedné stanice biologické kontroly kvality vody na úpravně vody v Praze Podolí a vzorky předkládaných krmiv. Celkem bylo analyzováno 74 vzorků svaloviny a 4 vzorky krmiv. Jako srovnávací materiál byl použit pstruh obecný získaný z prrirozeného prostř̌edí. Arsen byl 
stanovován metodou AAS. Obsah arsenu ve svalovině tržních pstruhů duhových ze sledovaných pstruhařství a ze stanice biologické kontroly lze hodnotit jako silně zvýšený ve srovnání s hodnotami zjištěnými u pstruhů obecných z přirozeného prostředí $(0.12 \pm 0.07$ $\left.\mathrm{mg} \cdot \mathrm{kg}^{-1}\right)$. Na dvou pstruhařstvích a na stanici biologické kontroly vody byl dokonce naměřen obsah arsenu převyšující hygienický limit $1 \mathrm{mg} \cdot \mathrm{kg}^{-1}$ platný pro sladkovodní ryby. Regresní analýzou dat byla prokázána významná korelace $(\mathrm{r}=0.57-0.94)$ mezi obsahem arsenu ve svalovině a hmotností ryb. Obsah arsenu v předkládaném krmivu BIOMAR a ALLER se pohyboval v rozmezí 2.5 až $3.1 \mathrm{mg} \cdot \mathrm{kg}^{-1}$. Z uvedených výsledků vyplynulo, že př́íčinou zvýšené koncentrace arsenu ve svalovině tržních pstruhů duhových je arsen př́tomný v krmivu. Na základě zjištěných skutečností doporučujeme věnovat pozornost této problematice i v následujícím období zejména se zaměřením na speciaci sloučenin arsenu.

\section{Acknowledgements}

This research was supported by the Ministry of Education, Youth and Physical Training of the Czech Republic (MSM Project No. 122200003)

\section{References}

COCKELL, KA, HILTON, JW, BETTGER, WJ 1991: Chronic toxicity of dietary disodium arsenate heptahydrate to juvenile rainbow trout (Oncorhynchus mykiss). Arch Environ Contam Toxicol 21: 518-527

ČELECHOVSKÁ, O 2001: Occurrence, toxicology and determination of arsenic in biological materials. In: Máchová, J., Svobodová, Z., Randák, T.: Proc. Conference Toxicity and Biodegradability of Matters Important in Water Management, RIFCH Vodňany, Aquachemie Ostrava, pp. 27-33 (in Czech, English Summary)

ČELECHOVSKÂ, O, SVOBODOVÁ, Z, RANDÁK, T 2001: Arsenic contents in fish tissues from selected localities of the Labe river. In: Máchová, J, Svobodová, Z, Randák, T: Proc. Conference Toxicity and Biodegradability of Matters Important in Water Management, RIFCH Vodňany, Aquachemie Ostrava, pp. 177183 (in Czech, English Summary)

DE GIETER, M, LEERMAKERS, M, VAN RYSSEN, R, NOYEN, J, GOEYENS, L, BAEYENS, W 2001: Total and toxic arsenic levels in North sea fish. ICEBAMO, Schielleiten, Austria, P II-7

Environmental Protection Agency (EPA) (2000): Target analytes Web page http:/ www.epa.gov/ostwater/ fishadvice/vol1/ch4. pdf.

CHAN, PC, HUFF, J 1997: Arsenic carcinogenesis in animals and humans. Environ Carcin Ecotox Rews 15: 83122

JAREŠ, P, MATĚJKA, Z, PARSCHOVÁ, H 2000: Sorpce arsenu na alumině. Chem Listy, 94: 822-843 (in Czech)

KAISE, T, KAMIDATE, Y, YAMADA, M, FURUSHO, Y, HANAOKA, K, FUJIWARA, K 2001: A rapid arsenic speciation analysis by a reversed phase semimicro column and an inductively coupled plasma mass spectrometer. ICEBAMO, Schielleiten, Austria, L-23

KHOKIATTIWONG, S, GOESSLER, W, FRANCESCONI, KA 2001: Arsenic compounds in tropical marine environments. ICEBAMO, Schielleiten, Austria, L-28

KIRBY, J, KRIKOWA, F, MAHER, W 2001: Tissue accumulation and distribution of arsenic compounds in three marine fish species: relationship to trophic position. ICEBAMO, Schielleiten, Austria, P II-6

LE, XC, LU, X, XING, J, GONG, Z, MA, M, MEI, N, WEINFELD, M 2001: Arsenic speciation, metabolism and health effects. ICEBAMO, Schielleiten, Austria, L-5

PERGANTIS, SA 2001: Development and application of electrospray tandem mass spectrometry for arsenic speciation. ICEBAMO, Schielleiten, Austria, L-21

PITTER, P 1999: Hydrochemie. Vydavatelství VŠCHT Praha, 568 pp. (in Czech)

POKORNÝ, J, ADÁMEK, Z, DVOŘÁK, J, ŠRÁMEK, V 1998: Pstruhařství. Informatorium, Praha, 242 pp. (in Czech)

RANDÁK, T, POKORNÝ, J 2001: Use of rainbow trout for checking water inflowing to the drinking water purification plants. In: Máchová, J, Svobodová, Z, Randák, T: Proc. Conference Toxicity and Biodegradability of Matters Important in Water Management, RIFCH Vodňany, Aquachemie Ostrava, pp. 113-121 (in Czech, English Summary)

ŘEHULKA, J 2001: Chemical monitoring of three water-supply reservois, using fish as bioindicators. J Czech Anim Sci 46: 217-230

SHIOMI, K, SUGIYAMA, Y, SHIMAKURA, K, NAGASHIMA, Y 1995: Arsenobetaine as the major arsenic compound in the muscle of 2 species of fresh-water fish. Appl Organometal Chem 9: 105-109

SVOBODOVÁ, Z, PIAČKA, V, ADÁMEK, Z 1995: Pstruh duhový jako indikátor kvality vody před její úpravou. In: Aktuální otázky vodárenské biologie, ČSVTS Praha, pp. 41-44 (in Czech) 
TAMAKI, S, FRANKENBERGER, WT 1992: Environmental biochemistry of arsenic. Rev Environ Contam Toxicol 124: 79-110

VELÍŠEK, J et al. 1999: Chemie potravin 3. Ossis, Tábor, 342 pp. (in Czech)

ŽLÁBEK, V, SVOBODOVÁ, Z, RANDÁK, T, MÁCHOVÂ, J 2002: Porovnání obsahu cizorodých látek v tkáních kapra obecného (Cyprinus carpio L.) a v sedimentu dna z rybníka Regent v letech 1992 a 2000. Bulletin VÚRH Vodňany, 38: 3-15 (in Czech, English summary) 